\title{
Social ostracisation- A study reflecting aftermath of female imprisonment
}

\author{
Budhiswatya Shankar Das \\ Psychiatric Social Worker, Assam Medical College and Hospital, Dibrugarh, Assam Contact Num- +91 \\ $9085664831+918130227525)$
}

\begin{abstract}
Women in contemporary prison face various problems, few resulting from their lives prior to imprisonment and others resulting from imprisonment itself. Social factors that marginalise their participation in mainstream society thus contribute in the rise in number of women in prison. Lack of support and social ostracisation during imprisonment and after release make their and their families' lives a veritable hell. Low level of education and poor legal awareness makes women more likely to serve longer sentences in prison. Navigation of a myriad of systems that often provide fragmented services can pose a barrier to successful reintegration. Here is a case study revealing the social effects faced by female offenders and their families on imprisonment.
\end{abstract}

Key words: Female offender, Parental imprisonment, Social ostracisation

\section{INTRODUCTION}

Our knowledge and understanding over the past few years of women's lives have increased. The new information has impacted and improved services in the fields of education, health, employment and reformatory measures. At present a need exists to coordinate knowledge from other fields into the justice system in order to develop effective programs for women. Research on women's pathway into crime indicates that gender matters. Abusive families and battering relationships are typical in the lives of female offenders. It has been noted that profound differences between the upbringing and the lives of men and women shape their patterns of criminal offending. Many women on the social and economic margins struggle to survive outside legitimate enterprises, which bring them into contact with criminal justice system. Historically correctional programs for women have been based on profiles of male offenders. However, the programmes, policies and services focus on the overwhelming number of men in the correction system often fail to identify alternatives that would be genderresponsive and culturally responsive to the specific needs of women. Moreover the impact of parental imprisonment on children goes far wider that just the relationship between the child and imprisoned parent. It affects all aspects of a child's life, from where they live and how they cope at school to their relationships with other family members and their standing in the local community. Many of the changes can be hard to deal with especially when a mother is imprisoned; a child's primary carer may change.From a Systems Perspective the life of a female offender is embedded in a complex social reality encompassing her relationships, personal history and the many contextual sociological forces inducing her criminality. The prospects of her rehabilitation and reintegration into society cannot validly be disentangled from this context. We describe a case from social work perspective which emphasise the psycho social aspects which pave women to take up offending ways. It also accentuates the issues faced by the individual and her family (especially her offspring) during legal proceedings and after imprisonment.

\section{Case study:}

Mrs. RB is a 53 year old widow, educated up to class VIII, hailing from Udalguri district, Assam is presently serving life imprisonment in Tezpur Central Jail, Assam for causing death of her husband. She had been running a tailoring school and living with two of her sons in her village. She reports that her husband was alcohol dependent and was charged with rape for which he was suspended from work. As expressed he was a person of promiscuous nature and did spend most of his time in gambling and consuming excess alcohol. RB was forced to play multiple roles and tried to provide necessary requirements to her sons and run the family effectively. As days passed by, her husband's demand for money and violence against her increased and during one such altercation, she in the process of self - defence and safety of her son had caused injury which lead to the death of her husband. She was imprisoned for three months and somehow managed to go on bail. She went ahead to fight the accusation for three years with great difficulty with the hope of getting her name cleared. Unfortunately, her lawyer demanded fee which she could not comply. She ultimately lost the case and was convicted with life imprisonment. She is supposed to complete five more years in the jail within the correctional 
setting.Initially during visits by her family it was often mentioned that they were not in cordial terms with the community people. No one spoke with her children, her brother was not getting much work and they were not being included in any kind of social gatherings. They had mentioned her about social compensation for integration in the community. R.B was not really prepared to perform all these rituals as she did not plan the act, which occurred at the spur of the moment as defence. When parole was granted and RB came home she was astonished and found hard to face the reality. She substantiated that her family was socially ostracised for her act of crime. All these days she heard about the seclusion but now she herself faced it with disgrace. She recognised how tough it was for her family to survive in such adverse circumstances. She realised that her sons and her brother's family were segregated from the rest of the community. According to R.B, her children were adversely affected where they had to discontinue with their studies, take up petty jobs to sustain themselves. Adding to all these her sons were typically called by names and were often mocked. In short, they lost their childhood in search of their existence. On the other hand her brother found it hard to earn his daily living; they were secluded and were not included in any social functions or occasions. They were not provided any kind of financial, social or emotional assistance in times of crisis. Thus it became mandatory for RB to perform certain rituals and pay a penalty to the community so that she and her family could integrate into usual village life. As instructed by village head man and influential figures of the community she performed certain ceremonial rites, fed the villagers and paid a penalty. As mntioned by RB after the rituals her family was accepted back yet the stigma persist in some form or the other.Presently RB's children are staying with her younger brother's family as she continues with her remaining tenure of serving the jail sentence. She feels that her imprisonment has psychologically affected her to a great extent. The emotional deprivation from her sons leads her to distress and constantly her thoughts go back to her children who are left behind. Due to financial constraint, they lack regular contact with their mother. Even when they come, their visits are short which lack quality time and privacy because of the correctional setting and rules. She feels most about her children and regrets that her children are deprived of parental love, care and protection. Thus her relationship with her children came under stress as she was apart and unable to maintain regular contact with them. She is concerned about the fact that her two sons have to live with the stain of crime by the mother and also the wayward ways of the father.

Now RB lives with the hope that once her tenure is over, she would like to live her life with dignity and help her children grow up to be respectable citizens. She wants to make up for the years she has been away from them. She realises that the journey ahead is a subtle one with immense challenges at every foot step. Yet she is reflective on the fact that the act was an accident and there was no intention which the legal system fails to take into account.

\section{DISCUSSION}

Many of the crimes committed by women are against spouse, ex-spouse or partner; women often report having been physically or sexually abused by the person they assaulted. The increased incarceration of women appears to be the outcome of forces that have shaped the crime policy, government policies that prescribe simplistic, punitive enforcement responses for complex social problems. Children of imprisoned parents are often described as the forgotten victims of imprisonment. When a mother goes to prison, their children are affected, usually adversely. Yet these effects are rarely considered in criminal justice processes. Maternal imprisonment frequently leaves children without adult care and supervision, compelling them to move in with relatives, friends, neighbours or other source of assistance and at times homelessness. Children may have to take on new roles following parental imprisonment in order to provide domestic, emotional or financial support for other family members (Gloria Larman and Ann Aungles, 1993). The focus on the offender means that the people around them are regularly ignored, from arrest to post-release. Many children experience ostracism, disapproval and scorn because of their association with imprisoned parents. Unlike 'other contexts of loss such as death or illness, loss of a family member because of incarceration seldom elicits sympathy and support from others and the stigma and feelings of isolation associated with being the family of a prisoner. Being contaminated in some way by the deeds of the offender, is central to many of the difficulties that children and families face (Joyce A. Arditti et al, 2003). This may also be compounded by community perceptions that prisoner parents are intrinsically bad parents. Inmate mothers are not only seen to offend against society, but also against their role as mothers (Ann Cunningham, 2001).

\section{CONCLUSION}

The characteristics of women offenders and their pathways to crime differ from male offenders. The system responds to them differently therefore there is the need for gender-responsive treatment and services. Gender difference persists at many levels in the contemporary society and there is an urgent need to address such issues, so that the transition phase from home to correctional system and back to community becomes an uncomplicated process. There is a critical need to develop a system of support within our communities that provides assistance to women transitioning from prison to the community. On the other hand experiences of 
abuse within the family are particularly likely for children with imprisoned mothers; do get affected by these issues at far higher rates than male prisoners or women in the general population. Getting exposed to such environments may heighten the risk that children develop anti social or criminal tendencies (though it is not necessary) and it should be taken into account when considering the best ways to support children affected by parental imprisonment. Thus social work in correctional setting in India has a challenging role to play and more initiatives need to be taken to smooth the process of entry and exit from reformatory institutions.

\section{REFERENCE}

[1] Ann Cunningham (2001) "Forgotten Families - the impact of imprisonment" in Family Matters Winter 2001, pp.36-7

[2] Children of Prisoners Library (2003) Impact of Parental Incarceration(Families and Corrections Network).

[3] Gloria Larman and Ann Aungles (1993) "Children of Prisoners and their outside carers: the invisible population" in Women and the Law: Proceedings of a conference held 24-26 September 1991, p. 263

[4] Joseph Murray (2007) 'The effects of imprisonment on families and children of prisoners" in A. Liebling \& S. Maruna (eds.) The effects of imprisonment, p.446

[5] Joseph Murray (2005) "The effects of imprisonment on families and children of prisoners" in A. Liebling \& S. Maruna (eds.) The effects of imprisonment, p.452

[6] Joseph Murray (2007) 'The cycle of punishment: Social exclusion of prisoners and their children' in Criminology and Criminal Justice Vol. 7, No. 1, p.59

[7] Joyce A. Arditti et al. (2003) "Saturday Morning at the Jail: Implications of Incarcerations for Families and Children" in Family Relations Vol 52, No. 3, p. 196

[8] Peter Opiyo (2007) "Joy amid despair: Women's Prison hosts families of inmates" in East African Standard 